JBR Paper

June 27, 1999

DIVERSIFICATION AND MARKET ENTRY CHOICES IN THE CONTEXT OF FOREIGN DIRECT INVESTMENT

\author{
Ram Mudambi \\ University of Reading and Case Western Reserve University \\ Susan McDowell Mudambi \\ John Carroll University
}
Address for correspondence: Dr. Susan McDowell Mudambi
Department of Management, Marketing and Logistics
Boler School of Business
John Carroll University
University Heights OH 44118

Phone: $\quad$ (216) 397-3094

FAX: $\quad$ (216) 397-1728

Email: $\quad \underline{\text { smudambi@jcu.edu }}$ 


\title{
DIVERSIFICATION AND MARKET ENTRY CHOICES IN THE CONTEXT OF
}

\section{FOREIGN DIRECT INVESTMENT}

\begin{abstract}
Multinational enterprises consider many factors when making decisions in the context of foreign direct investment (FDI). In deciding what to produce, the multinational enterprise (MNE) must decide whether to diversify or to concentration on its main line of business. This paper offers insights into influences on this choice, and identifies a number of conditions under which diversification is more likely to be chosen. Factors affecting the foreign entry mode decision are also analyzed. The international business literature has generally treated these strategic choices as independent. This paper introduces a more realistic selection model, in which the diversification choice and the entry mode choice are made sequentially and are therefore related. The model is tested using a data set of FDI into the United Kingdom by MNEs in engineering and related industries. The analysis indicates a strong relationship between the diversification choice and the entry mode decision. In virtually all cases, the statistical significance of the selection model is higher than that of the independent model, indicating an improvement over previous research. Overall, the choice of a diversification strategy has a significant positive effect on the probability of greenfield entry. The paper also identifies a number of managerially relevant factors affecting these relationships.
\end{abstract}




\section{DIVERSIFICATION AND MARKET ENTRY CHOICES IN THE CONTEXT OF FOREIGN DIRECT INVESTMENT}

\section{INTRODUCTION}

In many mature industrial markets, foreign market entry through foreign direct investment (FDI) is considered a primary source of future sales and profit growth. International diversification has been shown to produce economies of scale, scope and experience (e.g., Kogut, 1985, Kobrin, 1991), and stabilized returns (Lloyd, 1975; Caves, 1996). Key to international diversification is the choice of which foreign market to enter. Yet, beyond that choice lie two other important decisions. The first decision concerns the choice of output, or what should be produced in the foreign market. This is an important strategic decision for the multinational enterprise (MNE). The MNE must decide whether to expand its main line of business into the new market, an expansion strategy, or to produce products in a secondary or new line of business, a product diversification strategy. A second decision is of a more operational nature, and involves the choice over the mode of foreign entry. The MNE must decide whether to enter the foreign market through acquisition of a firm currently operating in the foreign market, or through the development of production capacity in the foreign market.

However, international diversification does not always enhance firm performance. Expanding into too many markets (or the wrong markets) too quickly can have devastating financial consequences. Although product diversification has long been a popular strategy, the effects of product diversification on firm performance are mixed and inconclusive (Hoskisson and Hitt, 1990; Sashi and Stern, 1995). Performance has been 
measured directly through measures of rates of return (Hitt, Hoskisson and Kim, 1997; Hoskisson and Hitt, 1990; Kim, Hwang and Burgers, 1993; Palepu, 1985; Thompson, 1985) and indirectly through measures of survival (Li and Guisinger, 1991; Mitchell, Shaver and Yeung, 1994). The dynamics are complex. For example, Hitt, Hoskisson and Kim (1997) found product diversification to play a moderating role between international diversification and performance. They suggested that firms should strive to integrate their international diversification and product diversification strategies in order to achieve synergies and optimal performance.

Past research has generally concentrated on either the product diversification decision or the foreign market entry decision, while the relationship between the decisions has rarely been investigated. The international business literature generally treats these decisions as independent. Studies of the mode of entry in the context of FDI tend to view a broad range of possibilities, considering different levels of control from wholly-owned subsidiaries through joint ventures to non-equity alliances (Agarwal and Ramaswami, 1992; Anderson and Gatignon, 1986; Aulakh and Kotabe, 1997; Larimo, 1995). These approaches are based on the transaction costs perspective and the implied OLI paradigm (Dunning, 1980; Hill, Hwang and Kim, 1990). While the impact on performance has been studied (Woodcock, Beamish and Makino, 1994; Sharma, 1998), the issue of diversification does not arise directly. A study by Busija, O'Neill and Zeithaml (1997) does link the two decisions. However, this study focuses on matching diversification-entry mode pairs with performance, rather than on investigating the link between the two decisions per se. 
This paper addresses product diversification in the context of FDI and foreign entry decision making by multinational enterprises (MNEs). It directly examines the link between product diversification strategy and the foreign mode of entry decision. This paper introduces a more realistic selection model of MNE strategic decision making on FDI, in which the output or diversification choice and the entry mode choice are made sequentially, and are therefore related.

The paper is organized as follows. The first section describes the main research questions in the context of relevant international business research. Next, we introduce a model of MNE strategic decision making on FDI, in which the diversification and entry mode choices are made sequentially. We describe how the model is estimated, using a data set of FDI into the UK by non-UK MNEs in engineering and related industries. We examine the relationship between the choices concerning diversification and the mode of foreign entry, and identify the key factors affecting these choices. The final section highlights the managerial implications of the research.

\section{RESEARCH QUESTIONS AND HYPOTHESES}

Central to each FDI decision is a strategic choice on output. Firms make and reevaluate their output choices in their domestic markets, and in each new and existing foreign market. Single business, or undiversified firms, concentrate on one main line of business, while product diversified firms operate in multiple and disparate product markets. Diversification is generally defined using 3 digit or 4 digit Standard Industrial Classification (SIC) codes, and is commonly calculated using an entropy measure of product diversification (Jacquemin and Berry, 1979; Palepu, 1985). Firms with a 
diversification entropy index of greater than $50 \%$ can be considered highly to moderately diversified, while firms with a diversification entropy index of $50 \%$ or less can be considered relatively undiversified. Since MNEs typically separate the domestic diversification decision and the foreign diversification decision, this necessitates a strategic choice on the level of product diversification in each foreign market.

Previous research has identified a number of factors influencing whether or not a firm chooses a product diversification strategy. In the international business literature, these factors are typically grouped into the two categories of industry-specific and firmspecific factors (Dunning, 1980; Sharma, 1998). Firm-specific factors include factors relating to the parent company, and factors relating to the subsidiary.

The first research objective is to identify the industry-specific and firm-specific factors that appear to underlie the choice of product diversification versus expansion in the context of FDI. In this study, industry-specific variables include: the rate of sales growth in the industry (INDGRW); the level of market power in the industry (CR5); and the type of industry. MNE firm-specific variables include: financial risk (FINRSK); opportunity cost (RORFF); R\&D intensity (RD); patenting activity (PATT); duration of operations or firm age (DT); and years of multinational experience (MULTI).

Subsidiary-specific variables include: the geographic scope or mandate of the subsidiary (GSCOPE); and FDI investment size (INVEST). These variables are drawn from the existing literature on MNE strategies (Hood and Young, 1979; Grant 1995). This study examines the importance of these variables in the decisions made by the firms in the data set. 
Hypothesis 1. The strategic choice of product diversification in an international context is related to industry-specific conditions of: a low rate of sales growth in the industry in the host country (INDGRW); the level of market power in the industry in the host country (CR5); and the type of industry.

Hypothesis 2. The strategic choice of product diversification in an international context is related to MNE firm-specific conditions of: low financial risk (FINRSK); low $R \& D$ intensity (RD); low patenting activity (PATT); shorter duration of operations (DT); and high levels of multinational experience (MULTI); and subsidiary-specific variables of: a broad geographic scope or mandate (GSCOPE); and smaller FDI investment size (INVEST).

The MNE must also choose its mode of foreign entry. Foreign entry choices can be simplified into entry by acquisition, and greenfield entry. A number of factors have been shown to affect the mode of entry decision. Industry-specific, firm-specific and location factors are involved. In this study, these include: industry type; the age or duration of operations of the parent firm (DT), size and multinational experience of the parent firm (MULTI); geographic scope of the subsidiary's mandate (GSCOPE); employment in the subsidiary (EMPL); relative levels of macroeconomic risk factors such as the inflation rate (RINF); relative levels of country risk (RLOCRSK); and levels of host country investment supports (GOVTAID). These variables are based on the predictions of theory (Anderson and Gatignon, 1986) and are comparable with those used in several related studies of FDI (Kogut and Singh, 1988; Li and Guisinger, 1991; Woodcock, Beamish and Makino, 1994; Mudambi, 1995; Phatak, Muralidharan and 
Chandran, 1996). This study examines the importance of these variables in the decisions made by firms in the data set.

Hypothesis 3. The choice of greenfield entry is related to industry-specific conditions of: the type of industry; and a higher rate of industry growth in the host country (RINF).

Hypothesis 4. The choice of greenfield entry is related to firm-specific conditions of: a younger age or duration of operations of the parent firm (DT); lower levels of multinational experience of the parent firm (MULTI); and narrow geographic scope of the subsidiary's mandate (GSCOPE).

Hypothesis 5. The choice of greenfield entry is related to location-specific conditions of: relatively high rates of inflation (RINF); higher relative levels of home country risk (RLOCRSK); and higher levels of host country investment supports (GOVTAID).

A key research question for this study is whether the decisions on product diversification and foreign mode of entry are best modeled as independent or as related. The importance of this question rests on the underlying implications of the two models. If the two decisions are related, what is the effect of ignoring this relationship, as the traditional independent models do? These are technical questions, but they have important managerial implications. Modeling the decisions as related makes more conceptual or practical sense, and is expected to fit the data better than the independent model does. Thus, the nature of the relationship between the decisions is an important research question. It is expected that a diversification choice will have a significant 
positive effect on the probability of a choice of greenfield entry. In other words, a strategic decision to diversify increases the probability that entry will occur through a greenfield mode, rather than an acquisition mode. This hypothesis is tested empirically, as described in the following section.

Hypothesis 6. The decisions on product diversification and foreign mode of entry are related.

\section{METHODOLOGY AND DATA}

\section{The Model}

Once a firm chooses to initiate or extend its multinational activities, it must then decide whether or not to adopt a product diversification strategy. The strategy choice presented here is of a firm that has already decided on a strategy of international diversification, and is next considering whether to implement this through expansion of its main line of business into the foreign market, or through product diversification in the foreign market. The diversification vs expansion decision is therefore a conditional one, as it is conditional on the MNE's decision to extend its multinational activities. This conditional approach is the standard approach to modal choice adopted in the theoretical literature on FDI (Czinkota et al, 1996; Devereux and Griffith, 1997; Grant, 1995; Mudambi and Ricketts, 1998).

In the model, firms choose a diversification strategy when the expected value of such a strategy exceeds the expected value of an expansion strategy. The variable of interest is as the expected difference between the expected value of launching a unit in a minor or new line of business and the expected value of launching a unit in the firm's 
main line of business. The difference between the expected value of setting up a diversified unit and setting up a unit in the firm's main line of business is denoted by DIVERS* ${ }_{\mathrm{i}}$. This variable is a function of measurable firm and industry attributes, which can be collected together in a vector, $\mathbf{Z}_{\mathrm{i}}$. The actual outcome also involves an error term, $\mathrm{e}_{\mathrm{i}}$, attributable at least in part to unobservable factors (e.g., Buckley and Carter, 1998; Casson, 1996; Caves, 1996). DIVERS $*_{i}$ itself is a latent variable and not observable, but the firm's strategic choice is observable. This generates a binary choice variable, $\operatorname{DIVERS}_{\mathrm{i}},(=1$, where the firm chooses FDI through diversification and $=0$, where FDI is undertaken through expansion). This is a dichotomous choice model, and the standard notation used in the literature on limited dependent variables may be used (Maddala, 1993). The choice for the $\mathrm{i}^{\text {th }}$ firm it is specified by:

$$
\begin{aligned}
\text { DIVERS }_{\mathrm{i}} & =\mu^{\prime} \mathbf{Z}_{\mathrm{i}}+\mathrm{e}_{\mathrm{i}} \\
\text { DIVERS }_{\mathrm{i}} & =1 \quad \text { if DIVERS }{ }_{\mathrm{i}}>0 ; \\
& =0 \text { otherwise }
\end{aligned}
$$

The second decision is the more operational one regarding mode of entry. Two key options are given, namely, entry via a greenfield operation, and entry via acquisition. The decision regarding foreign mode of entry is determined by firm, industry and location characteristics, with the binary DIVERS $\mathrm{i}_{\mathrm{i}}$ variable providing an additive difference. The variables that affect entry mode can be gathered together in a vector $\mathbf{X}_{\mathrm{i}}$, while DIVERS $\mathrm{i}_{\mathrm{i}}$ functions as a dummy variable. Several of the variables affecting the strategic choice of expansion versus diversification also affect the operational choice of 
foreign entry mode. Thus, many variables will enter both $\mathbf{Z}_{\mathrm{i}}$ and $\mathbf{X}_{\mathrm{i}}$. Since there are two entry modes under consideration, this decision also generates a binary variable, which we denote by GRNFLD ( $=1$ where the firm chooses greenfield entry and $=0$, where entry is undertaken through acquisition). This implies the following specification:

$$
\text { GRNFLD }_{\mathrm{i}}=\beta^{\prime} \mathbf{X}_{\mathrm{i}}+\theta \text { DIVERS }_{\mathrm{i}}+\mathrm{u}_{\mathrm{i}}
$$

As in (1), the error term in (2), $\mathrm{u}_{\mathrm{i}}$, is attributable in part to unobservable factors, some of which are the same as those determining $e_{i}$. This means that $u_{i}$ and $e_{i}$ are correlated and that DIVERS ${ }_{\mathrm{i}}$ suffers from problems of endogeneity. Endogeneity appears because DIVERS $\mathrm{D}_{\mathrm{i}}$ is not a 'given' characteristic, but rather a chosen strategy. Firms select into the two categories in DIVERS $\mathrm{i}_{\mathrm{i}}$ based on their resources and capabilities. Treating DIVERS $\mathrm{i}_{\mathrm{i}}$ as a normal exogenous variable leads to selectivity bias (Heckman, 1979). The effects of selectivity bias appear in both the mean and the variance of the estimator of $\theta$ in (2). The estimate of $\theta$ is biased in direction of the correlation between the errors $u_{i}$ and $e_{i}$. The estimated standard error of $\theta$ is biased downward, so the probability that it will appear significant is increased. For a technical treatment of the problem of selectivity bias and its effect on estimation, see Greene (1993). Shaver (1998) provides a detailed description of the problem in the context of the relationship between FDI modal choice and firm survival.

The hypothesis tests involve estimating (1) and (2). In order to analyze the relationship between the diversification decision and the entry mode decision, two ways of modeling the decision making are compared. The foreign mode of entry decision is 
first estimated from an independent model. The traditional, independent model does not account for the endogeneity of the diversification strategy, but treats diversification as exogenous, or determined by nature. Estimation involves estimating (2) using a single equation estimation method, where DIVERS is treated as an exogenous variable.

Next, the entry mode decision is estimated taking the diversification variable to be endogenous. This involves simultaneously estimating equation (1), the diversification decision, and equation (2), the entry mode decision. In the econometrics literature, a simultaneous equation system of the type defined by equations (1) and (2) is called a selection model (Heckman, 1979). We estimate the selection model using the so-called 'treatment' approach (Greene, 1993). This approach takes into account the entry mode decisions of firms using diversification strategies as well as the decisions of firms using expansion strategies.

\section{Data}

The study uses three levels of data: industry-level data, location-specific data and firm-level data. Industry level data were drawn at the 3-digit level based on the U.K. Standard Industrial Classification System 1992 - SIC(92). They are taken from the Report on the Census of Production, published by the UK's Central Statistical Office (1993, 1994), which is now part of the Office of National Statistics (ONS). Locationspecific data, comparing location characteristics of the host country (the UK) with those in the companies' home countries, were drawn from World Development Report (199596) published by the World Bank, and from the financial markets publication Euromoney. 
The firm-level data were derived from a large 1994 postal survey of FDI into the UK, supported by telephone and field interviews.

The sample frame for this survey was constructed from the comprehensive list of investment in the UK by non-UK firms during 1994 based on information compiled from the Invest in Britain Bureau of the Department of Trade and Industry (DTI), supplemented by Dun \& Bradstreet indexes (Dun \& Bradstreet 1994, 1995). The sample frame yielded a preliminary list of 614 firms with personal contact names, operating in 14 SIC(92) 3-digit industries. Entries where the investment was made for portfolio purposes were deleted. Also deleted were firms for which separate data for the parent firm were unavailable. The final usable sample frame consisted of 576 firms. Appendix 1 defines all the variables used in the estimation, and indicates the source of the data (survey or ONS). Descriptive statistics related to all these variables are presented in Table 1.

The survey was mailed out in two waves of 224 and 352 in March and April 1995. The first (pilot) wave focused on entries into Midlands region, which was the most successful region in the country in terms of attracting FDI. The second wave targeted entries in the rest of the country. The questionnaire was accompanied by a cover letter explaining the aims of the study, guaranteeing confidentiality and urging response. In order to improve the response rate, the questionnaire had to be short, concise and of current interest or salient to the respondent (Heberlein and Baumgartner, 1978). Fourteen days after the survey was mailed out, a reminder was faxed to all companies that had not yet responded. Twenty-one days after the survey was mailed out, a second reminder was faxed to companies that had still not responded. 
Overall, 236 responses were received to the mail survey (41\%). Of these, 3 were found to be UK firms mistakenly identified as non-UK firms, and 8 were unusable for various other reasons, leaving 225 (39\%) valid responses for evaluation. The response rate is well within the range expected for an unsolicited mail survey.

Non-response bias was investigated with the widely used method suggested by Armstrong and Overton (1977). This involved comparing early and late respondents. Two sets of late respondents were defined corresponding to those who responded after receiving the first faxed reminder and those who responded after receiving the second faxed reminder (the first set includes the second). Each set of late respondents was compared to the early respondents on the basis of six sample measures. The comparisons were carried out using a $\chi^{2}$ test of independence. In both cases, the responses from early and late respondents were virtually identical.

Survey responses were tested for veracity by comparing postal responses to responses obtained from field interviews. A total of 28 field interviews were carried out. Using a $\chi^{2}$ test of independence responses from field interviews were found to be virtually identical to those obtained from the postal survey on the basis of four sample measures. Finally, 20 respondents were randomly selected and interviewed by telephone to confirm their survey responses.

\section{ESTIMATION AND RESULTS}

Three sets of estimates are generated. The first set relates to (1) and provides a test of the variables that affect the choice of a diversification strategy. The second set consists of direct estimates of the mode of entry (2), treating DIVERS $\mathrm{i}_{\mathrm{i}}$, the diversification 
dummy as exogenous. The third set consists of estimates of (2) after accounting for selectivity bias, i.e., treating DIVERS as endogenous.

The strategic decision model specified by equation (1) is estimated using binomial probit. Maximum likelihood estimates of the independent model, i.e., assuming the diversification decision and the entry mode decision to be independent of each other, are reported in column (A) in Table 2. However, these estimates are not fully efficient. Estimating equations (1) and (2) as a system, taking into account the correlation between the two sets of errors yields efficient estimates of the variance-covariance matrix. Since the diversification decision is made first, the parameter estimates are unaffected, but the standard errors are corrected. The ' $t$ ' statistics based on the corrected standard errors are reported in column (B) in Table 2.

These results identify some industry and firm factors that seem to underlie the choice of diversification versus expansion in the context of FDI. They also pinpoint some areas where the simultaneity between the strategic and operational decisions seems to matter most. These are the variables whose statistical significance is altered by incorporating the selection process in the endogeneity of diversification decision. The fit of equation (1) to the data is very good, as measured by the likelihood ratio test. Further, comparing columns (A) and (B), there are preliminary indications that the selection model seems to fit the data better than the independent model, since virtually all the ' $t$ ' statistics improve. Thus, the discussion of the results will focus on the selection model. 


\section{Influences on the Diversification Decision}

The host country's rate of sales growth in the entered industry (INDGRW) exerts a strong negative influence on the probability that a diversification strategy will be adopted. If there is a high growth rate in the parent firm's main line of business, the probability of a diversification strategy falls. However, the level of market power in the entered industry (CR5) does not seem to have a significant effect. Differences in diversification strategy between firms in the electrical engineering group (ELEC) and the chemical engineering group (the index group) seem to be statistically insignificant. However, firms in the mechanical engineering group (MECH) seem to be significantly less likely to pursue a diversification strategy than those in the index group.

Thus, testing Hypothesis 1 reveals support for the relationship between product diversification and industry-specific conditions of a low rate of sales growth in the industry in the host country, and the type of industry. A lack of support is found for the relationship between product diversification and the level of market power in the industry in the host country.

Next, firm specific factors related to the parent firm are examined. The financial variables do not seem to have a significant effect on diversification strategy. Neither firm-specific risk as measured by the variance of parent profits (FINRSK), nor the rate of return on central cash balances (i.e., free cash flows) (RORFF), seem to have a significant effect. The firm's research and development intensity as measured by its $\mathrm{R} \& \mathrm{D} / \mathrm{sales}$ ratio (RD) has a negative effect, but its significance is borderline. Its patenting activity (PATT) does not seem to exert a significant influence. The firm's experience as 
measured by the total duration of its operations (DT) seems to have a negative influence. However, its multinational experience (MULTI) is found to have a significant positive effect. Thus, while increasing total experience seems to indicate a lower propensity to undertake a diversification strategy, increasing multinational experience seems to have the opposite effect in the context of FDI. Finally, subsidiary-specific factors are examined. Here, the geographic scope of the subsidiary's output mandate (GSCOPE) appears to have a significant positive effect on diversification strategy. In other words, subsidiaries with narrow geographic mandates, and therefore a local focus, are more likely to be set up in the parent's main line of business. Subsidiaries with wide geographic mandates, and therefore re-export responsibilities, are more likely to be set up in diversified businesses. This is an issue of subsidiary strategic independence. However, the size of the investment in the subsidiary (INVEST) is found to have a significant negative effect. Large investments by the parent firm are likely to be made in an expansion strategy. Risk is the issue here.

To summarize the results of testing Hypothesis 2, product diversification in an international context is related to MNE firm-specific conditions of low R\&D intensity; shorter duration of operations; and high levels of multinational experience. A relationship is also supported for subsidiary-specific variables of a broad geographic scope or mandate, and smaller FDI investment size. Lack of support is found for the relationship between product diversification and low financial risk, and low patenting activity. 


\section{Influences on the Foreign Mode of Entry Decision}

A number of the variables appear to affect the foreign mode of entry decision. Amongst the industry variables, both aspects of Hypothesis 3 are supported. Type of industry appears to matter, as firms in mechanical engineering and related industries (MECH) seem to have a higher probability of entering through a greenfield mode, compared to the chemical engineering reference group (CHEM). Secondly, the choice

of greenfield entry is related to a higher rate of industry growth in the host country.

Regarding firm variables, age of the parent firm (DT), multinational experience (MULTI), and the geographic scope of the subsidiary's output mandate (GSCOPE), seem to be negatively related to the probability of greenfield entry. Thus, all three aspects of Hypothesis 4 are supported. The choice of greenfield entry is related to firm-specific conditions of a young age of the parent firm; lower levels of multinational experience of the parent firm, and narrow geographic scope of the subsidiary's mandate.

Finally, amongst the location variables, both a higher relative rate of home country inflation (RINF) and a higher relative level of home country risk (RLOCRSK) are associated with a higher probability of greenfield entry in the host country (the UK). Higher levels of UK government investment supports (GOVTAID) seem to be associated with a lower probability of greenfield investment. This may be because of the nature of the industry groups in the sample. A significant portion of UK government investment support is geared toward re-development and regeneration in economically backward areas (Wren, 1996). In engineering and related industries, such areas tend to be the traditional manufacturing areas with large numbers of acquisition targets. Consequently, this estimate is probably picking up an industry effect rather than a location effect. 
Thus, two of the three aspects of Hypothesis 5 are supported. The choice of greenfield entry is related to location-specific conditions of relatively high rates of inflation, and higher relative levels of home country risk, while the level of host country investment supports is inversely related.

\section{The Relationship between the Diversification and the Entry Mode Decisions}

In order to analyze the relationship between the diversification decision and the entry mode decision, the independent model and the selection model are compared. Maximum likelihood estimates of a binomial probit specification of the independent model are reported in column (A) in Table 3. The selection model is also estimated using maximum likelihood. This estimation methodology incorporates the correlation between equation (1), the diversification decision, and equation (2), the entry mode decision, and is fully efficient. Merino and Rodriguez (1997) utilized a closely related procedure in the context of diversification decisions. Table 3 presents the probit results of the two models.

To test Hypothesis 6 regarding the independence of the two decisions, the first step is to examine the selection parameters and the correlation between the error terms. If the selection model is the correct specification, then the standard error of the conditional distribution will consist of two parts - one from the error term, and one from the selection process. Further, the selection model implies a statistically significant correlation between the error terms of equations (1) and (2). As shown in Table 3, the selection parameters, $\sigma$, the estimated contribution of the selection process to the standard error of the conditional distribution and $\rho$, the estimated correlation between the error terms in equations (1) and (2) are both extremely significant. In particular, the 
correlation between the error terms is very large, suggesting a serious problem of selection bias. The two estimates of the diversification strategy variable (DIVERS) reflect both types of selection bias effects. First, the negative correlation between the errors means that the size of the coefficient on in the independent model in column (A) is biased downward. Second, the ' $t$ ' statistic on the coefficient in the independent model is biased upward. The presence of selection bias indicates endogeneity.

These findings imply that the decisions on diversification and foreign mode of entry are related, and provide support for Hypothesis 6. In both models, the diversification strategy variable (DIVERS) has a significant positive effect on the probability of greenfield entry. Thus, a strategic decision to diversify increases the probability that entry will occur through a greenfield mode. However, as predicted by the model, the statistical significance of this result is much lower in the selection model and declines from the $1 \%$ level to the $5 \%$ level. This strong relationship between the diversification and greenfield entry decisions provides strong support for Hypothesis 6.

Comparing the coefficient estimates on the control variables in column (A) and column (B), we note some similarities and some crucial differences in the results of the two models. Perhaps most importantly, in virtually all cases, the statistical significance in the selection model is higher. Several differences between the two sets of estimates are especially noteworthy. The independent model fails to estimate a significant effect associated with sales growth in the subsidiary industry (INDGRW), with the multinational experience of the parent firm (MULTI) and with the size of the inward investment (INVEST). However, the selection model estimates a significant positive effect associated with the first and third variables and detects a significant negative effect 
of the second. Thus, higher rates of industry growth and higher levels of project investment increase the probability of greenfield entry. However, greater multinational experience of the parent firm seems to raise the probability of acquisition entry. Finally, in the independent model, global sales of the parent firm (GSALES) have a significant negative influence on the probability of greenfield entry. This significant effect disappears in the selection model, suggesting that global sales are correlated with the selection process. In other words, the level of global sales is a factor in the strategic decision making process regarding diversification.

Overall, the selection model appears to fit the data better than the independent model does, and indicates that the selection model is an improvement over the independent model. The results support for Hypothesis 6, namely that the decisions on product diversification and foreign mode of entry are related. Managers appear to take the product diversification decision into consideration when deciding on the foreign entry mode. In particular, the diversification strategy variable has a significant positive effect on the probability of greenfield entry.

\section{MANAGERIAL IMPLICATIONS}

Firms make tough choices on FDI, product diversification, and foreign mode of entry in an environment of uncertainty. MNEs, however wise, never possess full information about their own capabilities, much less the capabilities of their competitors, the needs of their customers, or the potential impact of a range of factors in the business environment. This study has examined a number of relevant factors affecting decisions in a FDI context. The findings of this study provide potentially helpful information about 
factors affecting past decisions, and can inform and possibly improve future MNE decision making. In particular, these results offer insights into the various influences on the strategic choice of diversification versus expansion, and on the choice of mode of foreign entry mode. Secondly, the results shed light into the relationship between the strategic decision on diversification and the operational decision on mode of foreign entry.

Amongst engineering firms, diversification is significantly more likely to be chosen under certain conditions. This study identified the following conditions favorable for a diversification choice: the host country's rate of sales growth in the entered industry is relatively low; the firm is in the chemical engineering or electrical engineering group (instead of the mechanical engineering group); the firm has a relatively lower research and development (R\&D) intensity; the firm has more multinational experience; the firm is younger, i.e., it has a lower total duration of operations; the subsidiary is set up with a broader geographic mandate; and the investment in the subsidiary is relatively smaller. In the study, diversification is not significantly affected by: level of market power in the entry market; firm-specific risk, as measured by variance of parent profits; rate of return on free cash flows; and the firm's patenting experience.

Factors which appear to significantly and positively related to greenfield entry in the study include: the firm is in the mechanical engineering and related industry; higher rates of industry growth in the entered industry; higher relative rate of home country inflation; higher relative level of home country risk; lower levels of UK government investment supports; younger age of the parent firm; lower degree of multinational experience of the parent firm; and narrower scope of the subsidiary's output mandate. 
The study also provides insights into the relationship between diversification and mode of foreign entry. Overall, the choice of a diversification strategy has a significant positive effect on the probability of greenfield entry. A number of managerially relevant factors affect this relationship. First, comparisons of the results of the independent and selection models reveal that, in virtually all cases, the statistical significance of the selection model is higher. This indicates that the selection model represents a conceptual and empirical improvement over the independent model used in previous research. Managers do not, and perhaps should not, make the product diversification decision completely independently from the foreign entry mode decision.

No one study can have the final word on such a complex area of international business. This study is best viewed in the context of the extensive previous research in the area. The findings would benefit from further testing in other country markets, and with a sample of firms in a wider range of industry types. Although performance data is often difficult to obtain, future studies in this area would be enhanced by the inclusion of investment performance measures. This would help to better determine which strategic and operational choices are most likely to facilitate the meeting or exceeding of MNE investment objectives. MNEs face many challenges as they strive to proactively face issues of global competition and industrial consolidation. Informed decision making on product diversification and foreign entry mode remain worthwhile and practical research objectives. 
APPENDIX

VARIABLE DEFINITIONS

\begin{tabular}{|c|c|c|}
\hline VARIABLE & DEFINITION & SOURCE \\
\hline \multicolumn{3}{|c|}{ Dependent variables } \\
\hline \multirow[t]{2}{*}{ DIVERS } & $\begin{array}{l}0 \text {, if entry into the UK is in parent's main } \\
\text { line of business* }\end{array}$ & \multirow{2}{*}{$\begin{array}{l}\text { Survey, supplemented by } \\
\text { company annual reports } \\
\text { and ONS data }\end{array}$} \\
\hline & 1, otherwise & \\
\hline \multirow[t]{2}{*}{ GRNFLD } & 1 , if entry into the UK is greenfield & \multirow{2}{*}{$\begin{array}{l}\text { Survey, supplemented by } \\
\text { ONS data }\end{array}$} \\
\hline & 0 , otherwise & \\
\hline \multicolumn{3}{|c|}{ Industry variables } \\
\hline INDGRW** & $\begin{array}{l}\text { Average output growth rate in UK subsidiary } \\
\text { industry, } 1989-94,(\%)\end{array}$ & ONS data \\
\hline $\mathrm{CR}^{* * *}$ & $\begin{array}{l}\text { Five-firm concentration ratio in UK } \\
\text { subsidiary industry, } 1994\end{array}$ & ONS data \\
\hline \multirow[t]{2}{*}{ ELEC } & $\begin{array}{l}\text { 1, if UK subsidiary is in an electrical } \\
\text { engineering and related industry }\end{array}$ & \multirow[t]{2}{*}{ ONS data } \\
\hline & 0 , otherwise & \\
\hline \multirow[t]{2}{*}{$\mathrm{MECH}$} & $\begin{array}{l}\text { 1, if UK subsidiary is in a mechanical } \\
\text { engineering and related industry }\end{array}$ & \multirow[t]{2}{*}{ ONS data } \\
\hline & 0, otherwise & \\
\hline \multirow[t]{2}{*}{ CHEM } & $\begin{array}{l}\text { 1, if UK subsidiary is in a chemical } \\
\text { engineering and related industry }\end{array}$ & \multirow[t]{2}{*}{ ONS data } \\
\hline & 0, otherwise & \\
\hline \multicolumn{3}{|c|}{ Location variables } \\
\hline RLOCRSK & $\begin{array}{l}\text { Relative country risk, home country/host } \\
\text { country (U.K.); average, 1993-1994 }\end{array}$ & Euromoney*** \\
\hline RINF & $\begin{array}{l}\text { Relative inflation rate, home country/host } \\
\text { country (U.K.); average, 1991-1994 }\end{array}$ & $\begin{array}{l}\text { World Development } \\
\text { Report (World Bank) }\end{array}$ \\
\hline GOVTAID & $\begin{array}{l}\text { value of UK government investment } \\
\text { incentives (GBP million) }\end{array}$ & ONS data \\
\hline \multicolumn{3}{|c|}{ Firm variables } \\
\hline FINRSK & $\begin{array}{l}\text { Variance of parent firm's corporate rate of } \\
\text { return on capital, 1986-1994 }\end{array}$ & $\begin{array}{l}\text { Survey, supplemented by } \\
\text { company annual reports }\end{array}$ \\
\hline RORFF & $\begin{array}{l}\text { Rate of return on corporate liquid funds, } \\
1993-4\end{array}$ & Survey \\
\hline DT & Duration of operations or age of parent firm & $\begin{array}{l}\text { Survey, supplemented by } \\
\text { company annual reports }\end{array}$ \\
\hline MULTI & $\begin{array}{l}\text { Duration of parent firm's prior multinational } \\
\text { activity }\end{array}$ & Survey \\
\hline $\mathrm{RD}$ & Parent firm's total R\&D intensity & $\begin{array}{l}\text { Survey, supplemented by } \\
\text { company annual reports }\end{array}$ \\
\hline
\end{tabular}




\begin{tabular}{|l|l|l|}
\hline PATT & $\begin{array}{l}\text { Parent firm, number of US patents filed, } \\
1986-94\end{array}$ & $\begin{array}{l}\text { Survey, supplemented by } \\
\text { company annual reports }\end{array}$ \\
\hline GSCOPE & $\begin{array}{l}\text { Output mandate of UK subsidiary } \\
\text { 1=UK only; 2=UK\& Europe; 3=Worldwide }\end{array}$ & Survey \\
\hline INVEST & $\begin{array}{l}\text { Total inward investment in UK subsidiary } \\
\text { (GBP million) }\end{array}$ & Survey \\
\hline GSALES & $\begin{array}{l}\text { Non-UK sales of parent firm, 1993-94 } \\
\text { (US\$ million) }\end{array}$ & $\begin{array}{l}\text { Survey, supplemented by } \\
\text { company annual reports }\end{array}$ \\
\hline EMPL & Employment in UK subsidiary ('00s), 1994 & $\begin{array}{l}\text { Survey, supplemented by } \\
\text { ONS data }\end{array}$ \\
\hline
\end{tabular}

* The parent firm's main line of business is defined to be its largest non-UK sales segments whose cumulative contribution to the entropy index of diversification just exceeds $50 \%$.

** Industries are defined as SIC(92) 3-digit industry groups

*** Euromoney risk index, which includes economic performance, political risk, debt indicators, debt default, credit ratings, access to bank, short-term and capital market finance, and the discount on forfeiting 


\section{REFERENCES}

Agarwal, S. and Ramaswami, S.N., Choice of Foreign Market Entry Mode: Impact of Ownership, Location and Internalization Factors. Journal of International Business Studies 23 (1) (1992): 1-27.

Anderson, E. and Gatignon, H., Modes of Foreign Market Entry: A Transaction Cost Analysis and Propositions. Journal of International Business Studies 17(3) (1986): 1-26.

Armstrong, J.S. \& Overton, T., Estimating Non-Response Bias in Mail Surveys. Journal of Marketing Research 14(3) (1977): 396-402.

Aulakh, P. and Kotabe, M., Antecedents and Performance Implications of Channel Integration in Foreign markets. Journal of International Business Studies 28(1) (1997): 145-175.

Buckley, P.J. and Carter, M.J., The Economics of Business Process Design in Multinational Firms, in The Organisation of the Firm: International Business Perspectives, R. Mudambi and M.Ricketts, eds., Routledge, London. 1998, pp. 56-78.

Busija, E.C., O’Neill, H.M. and Zeithaml, C.P., Diversification Strategy, Entry Mode, and Performance: Evidence of Choice and Constraints. Strategic Management Journal 18(4) (1997): 321-327.

Casson, M.C., The Nature of the Firm: Information Synthesis and Entrepreneurial Organisation. Management International Review 36(1) (1996): 55-94.

Caves, R.E., Multinational Enterprise and Economic Analysis, $2^{\text {nd }}$ ed., Cambridge University Press, Cambridge. 1996.

Central Statistical Office, Report on the Census of Production, HMSO, London. 1993.

Central Statistical Office, Report on the Census of Production, HMSO, London. 1994.

Czinkota, M.R., Ronkainen, I.A. and Moffett, M.H., International Business, $4^{\text {th }}$ ed., The Dryden Press, New York. 1996.

Devereux, M.P. and Griffith, R., Taxes and the Location of Production: Evidence from a Panel of US Multinationals. Working Paper, Institute for Fiscal Studies, London. 1997.

Dun \& Bradstreet, Business Register. Dun \& Bradstreet, London. 1994.

Dun \& Bradstreet, Business Register. Dun \& Bradstreet, London. 1995.

Dunning, J.H., Toward an Eclectic Theory of International Production: Some Empirical Tests. Journal of International Business Studies 11(1)(1980): 9-31. 
Grant, R.M., Contemporary Strategy Analysis: Concepts, Techniques, Applications, 2nd ed., Blackwell, Oxford. 1995.

Greene, W.H., Econometric Analysis, $2^{\text {nd }}$ ed., Macmillan, New York. 1993.

Heberlein, T.A. and Baumgartner, R. 1978, Factors Affecting Response Rates to Mailed questionnaires: A Quantitative Analysis of the Published Literature. American Sociological Review 43(4) (1978): 447-462.

Heckman, J., Sample Selection Bias as a Specification Error. Econometrica (1979): 153161.

Hill, C.W.L., Hwang. P. and Kim, W.C., An Eclectic Theory of the Choice of International Entry Mode, Strategic Management Journal 11(2) (1990): 117-128.

Hitt, M.A., Hoskisson, R.E. and Kim, H., International Diversification: Effects on Innovation and Firm Performance in Product-Diversified Firms. Academy of Management Journal 40(4) (1997): 767-798.

Hood, N. and Young, S., The Economics of Multinational Enterprise, Longman, London. 1979.

Hoskisson, R.E. and Hitt, M.A., Antecedents and Performance Outcomes of Diversification: A Review and Critique of Theoretical Perspectives. Journal of Management 16 (1990): 461-509.

Jacquemin, A.P. and Berry, C.H., The Entropy Measure of Diversification and Corporate Growth. Journal of Industrial Economics, 27 (1979): 359-369.

Kim, W.C., Hwang, P. and Burgers, W.P., Multinationals' Diversification and the Risk/Return Trade-off. Strategic Management Journal, 14 (1993): 275-286.

Kobrin, S.J., An Empirical Analysis of the Determinants of Global Integration. Strategic Management Journal 12 (1991): 17-37.

Kogut, B., Designing Global Strategies: Comparative and Competitive Value Added Chains, Part 1. Sloan Management Review 27 (Summer 1985): 15-28.

Kogut, B. and Singh, H., The Effect of National Culture on the Choice of Entry Mode. Journal of International Business Studies 19(3) (1988): 411-432.

Larimo, J., The Foreign Direct Investment Decision Process: Case Studies of Different Types of Decision Processes in Finnish Firms. Journal of Business Research 33 (1) (May 1995): 25-55. 
Li, J. and Guisinger, S., Comparative Business Failures of Foreign-Controlled Firms in the United States. Journal of International Business Studies, 22(2) (1991): 209-224.

Lloyd, W.P., International Portfolio Diversification of Real Assets: An Inquiry. Journal of Business Research 3 (2) (April 1975): 113-120.

Maddala, G.S., Limited-Dependent and Qualitative Variables in Econometrics, Cambridge University Press, Cambridge. 1983.

Merino, F. and Rodriguez, D.R. A Consistent Analysis of Diversification Decisions with Non-Observable Firm Effects. Strategic Management Journal 18(9) (1997): 733-743.

Mitchell, W., Shaver, J.M. and Yeung, B., Foreign Entrant Survival and Foreign Market Share. Strategic Management Journal 15(7) (1994): 555-567.

Mudambi, R., The MNE Investment Location Decision: Some Empirical Evidence. Managerial and Decision Economics 16 (1995): 249-257.

Mudambi, R. and Ricketts, M.J. 1998. Economic Organisation and the Multinational Firm, in The Organisation of the Firm: International Business Perspectives, R. Mudambi and M.Ricketts, eds., Routledge, London. 1998, pp. 1-18.

Palepu, K., Diversification Strategy, Profit Performance, and the Entropy Measure of Diversification. Strategic Management Journal 6 (1985): 239-255.

Phatak, A., Muralidharan, R. and Chandran, R., A Study of the Impact of Location Specific and Moderating Factors on the Choice of Entry Mode in Thailand, Malaysia, and Indonesia. Journal of Euro-Marketing 4(3-4) (1996): 37-53.

Sashi, C.M. and Stern, L.W., Product Differentiation and Market Performance in Producer Goods Industries. Journal of Business Research 33 (2) (June 1995): 115-127.

Sharma, A., Mode of Entry and Ex-Post Performance. Strategic Management Journal 19(9) (1998): 879-900.

Shaver, J.M., Accounting for Endogeneity When Assessing Strategy Performance: Does Entry Mode Choice Affect FDI Survival? Management Science 44(4) (1998): 571-585.

Thompson, R.S., Risk Reduction and International Diversification: An Analysis of Large UK Multinational Companies. Applied Economics 17(3) (1985): 529-541.

Woodcock, C.P., Beamish, P.W. and Makino, S., Ownership-Based Entry Mode Strategies and International Performance. Journal of International Business Studies 25(2) (1994): 253-273. 
World Bank, World Development Report, Washington DC, The World Bank, Washington, D.C. 1995-1996.

Wren, C., Industrial Subsidies: The UK Experience, Macmillan, London. 1996. 
TABLE 1

\section{DESCRIPTIVE STATISTICS}

\begin{tabular}{|c|c|c|}
\hline Variable & Mean & S.D. \\
\hline DIVERS & 0.2089 & 0.407 \\
\hline GRNFLD & 0.4667 & 0.500 \\
\hline INDGRW & 5.5911 & 3.788 \\
\hline CR5 & 24.5644 & 16.403 \\
\hline ELEC & 0.4267 & 0.496 \\
\hline MECH & 0.3289 & 0.471 \\
\hline RLOCRSK & -48.0796 & 108.300 \\
\hline RINF & 111.8044 & 23.762 \\
\hline GOVTAID & 1.2222 & 1.058 \\
\hline FINRSK & 3.6927 & 5.160 \\
\hline RORFF & 0.0359 & 0.018 \\
\hline DT & 7.9924 & 5.756 \\
\hline MULTI & 4.4578 & 4.243 \\
\hline RD & 4.1822 & 1.110 \\
\hline PATT & 1.4889 & 0.755 \\
\hline GSCOPE & 2.0267 & 12.474 \\
\hline INVEST & 22.4117 & 327.726 \\
\hline GSALES & 374.6445 & 11.667 \\
\hline EMPL & 17.1870 & \\
\hline & & \\
\hline & & \\
\hline
\end{tabular}


TABLE 2

\section{ESTIMATING DIVERSIFICATION CHOICE: PROBIT RESULTS}

(Maximum Likelihood Estimates)

Regressand: $\quad$ DIVERS $=1$ (diversification strategy);

DIVERS $=0$ (expansion strategy)

Positive coefficients indicate a higher probability of observing a diversification strategy

\begin{tabular}{|c|c|c|}
\hline Regressor & $\begin{array}{c}\mathbf{( A )} \\
\text { Coefficient } \\
\text { (uncorrected' } t \text { ' statistic) }\end{array}$ & $\begin{array}{c}\text { (B) } \\
\text { Corrected ' } t \text { ' } \\
\text { statistic }\end{array}$ \\
\hline Constant & $0.242 \quad(0.48)$ & 0.53 \\
\hline INDGRW & $-0.097 \quad(3.17)^{* *}$ & $3.75 * *$ \\
\hline CR5 & $-0.766(1.15)$ & 1.45 \\
\hline ELEC & $-0.077 \quad(0.30)$ & 0.40 \\
\hline $\mathrm{MECH}$ & $-1.009 \quad(2.93)^{* *}$ & $2.94 * *$ \\
\hline FINRSK & $-0.025 \quad(1.02)$ & 1.11 \\
\hline RORFF & $-9.813(1.58)$ & 1.82 \\
\hline $\mathrm{RD}$ & $-0.062 \quad(1.51)$ & 1.92 \\
\hline PATT & $0.068 \quad(0.70)$ & 1.11 \\
\hline DT & $-0.134 \quad(1.60)$ & $2.32 *$ \\
\hline MULTI & $0.068 \quad(2.06)^{*}$ & $2.56^{*}$ \\
\hline GSCOPE & $0.258 \quad(1.73)$ & $2.19 *$ \\
\hline INVEST & $-0.009 \quad(2.53)^{*}$ & $2.51 *$ \\
\hline $\mathrm{N}$ & \multicolumn{2}{|c|}{225} \\
\hline Log-likelihood & \multicolumn{2}{|c|}{-89.8474} \\
\hline Restricted Log-likelihood $(\beta=0)$ & \multicolumn{2}{|c|}{-115.3082} \\
\hline $\begin{array}{c}\text { Likelihood Ratio Test: } \chi^{2}(12) \\
\text { 'p' value }\end{array}$ & \multicolumn{2}{|c|}{$\begin{array}{l}50.9216 \\
(0.000)\end{array}$} \\
\hline Iterations & \multicolumn{2}{|l|}{6} \\
\hline
\end{tabular}

* Coefficient significant at the $5 \%$ level

** Coefficient significant at the $1 \%$ level 
TABLE 3

ESTIMATING FOREIGN MODE OF ENTRY CHOICE: PROBIT RESULTS

(Maximum Likelihood Estimates)

Regressand: $\quad$ GRNFLD $=1$ (greenfield entry);

GRNFLD $=0$ (acquisition entry)

Positive coefficients indicate a higher probability of observing greenfield entry

\begin{tabular}{|c|c|c|}
\hline Regressor & $\begin{array}{l}\text { (A) Independent Model } \\
\text { Coefficient (' } t \text { ' statistic) }\end{array}$ & $\begin{array}{c}\text { (B) Selection Model } \\
\text { Coefficient (' } t \text { ' statistic) }\end{array}$ \\
\hline Constant & $0.207 \quad(0.25)$ & $0.257 \quad(1.43)$ \\
\hline INDGRW & $0.042 \quad(1.33)$ & $0.022(3.23)^{* *}$ \\
\hline CR5 & $-0.0002(0.03)$ & $0.0012(0.80)$ \\
\hline ELEC & $-0.161 \quad(0.61)$ & $-0.035 \quad(0.62)$ \\
\hline $\mathrm{MECH}$ & $1.309(4.00)^{* *}$ & $0.436(4.01)^{* *}$ \\
\hline RLOCRSK & $0.005 \quad(2.64)^{* *}$ & $0.839 \times 10^{-3}(3.85)^{* *}$ \\
\hline RINF & $0.013(2.20)^{*}$ & $0.0028 \quad(2.24)^{*}$ \\
\hline GOVTAID & $-0.213(2.06)^{*}$ & $-0.052 \quad(2.58)^{* *}$ \\
\hline FINRSK & $0.034 \quad(1.66)$ & $0.008 \quad(1.36)$ \\
\hline RORFF & $-0.108 \quad(0.02)$ & $2.185 \quad(1.39)$ \\
\hline DT & $-0.082(2.90)^{* *}$ & $-0.0157 \quad(2.65)^{* *}$ \\
\hline MULTI & $-0.038 \quad(1.12)$ & $-0.0164(2.01)^{*}$ \\
\hline GSCOPE & $-0.360(2.38)^{*}$ & $-0.121(3.18)^{* *}$ \\
\hline INVEST & $0.0016 \quad(0.46)$ & $0.0022 \quad(2.66)^{* *}$ \\
\hline GSALES & $-0.14 \times 10^{-5}(4.00)^{* *}$ & $0.522 \times 10^{-5}(0.08)$ \\
\hline DIVERS & $0.634(2.67)^{* * *}$ & $0.760 \quad(2.04)^{*}$ \\
\hline \multicolumn{3}{|l|}{ Estimates of the selection process } \\
\hline $\begin{array}{c}\sigma \text { est.standard error of the conditional } \\
\text { distribution }\end{array}$ & - & $0.439(10.25)^{* *}$ \\
\hline$\rho$ est.correlation btwn. error terms & - & $-0.853(19.82)^{* *}$ \\
\hline \multicolumn{3}{|c|}{ Diagnostics } \\
\hline $\mathrm{N}$ & 225 & 225 \\
\hline Log-likelihood & -93.7075 & -257.5215 \\
\hline Restricted Log-likelihood $(\beta=0)$ & -155.4577 & -297.2482 \\
\hline $\begin{array}{l}\text { Likelihood Ratio Test: } \chi^{2}(15) \\
\text { 'p' value }\end{array}$ & $\begin{array}{c}123.5005 \\
(0.000)\end{array}$ & $\begin{array}{l}79.4534 \\
(0.000)\end{array}$ \\
\hline Iterations & 6 & 3 \\
\hline
\end{tabular}

* $\quad$ Coefficient significant at the $5 \%$ level

** Coefficient significant at the $1 \%$ level 